\title{
Scaling simulation resulting from mixing predicted model between Mishrif formation water and different waters injection in Basrah oil field, southern Iraq
}

\author{
Hussein B. Ghalib ${ }^{1}$ Inass Abdal Razaq Almallah ${ }^{1}$ \\ Received: 18 September 2017 / Accepted: 26 September 2017 / Published online: 5 October 2017 \\ (c) The Authors 2017. This article is an open access publication
}

\begin{abstract}
Dependable scale prediction is of critical importance in the selection of suitable injection water and the development of an effective scale management strategy. The present study focuses on the Mishrif reservoir in the West Qurna oilfield. In this reservoir, we use compositional modeling to understand the interplay between multiphase flow, phase behavior, and geochemical reactions under reservoir and injection conditions relevant to the field. The numerical model PHREEQC was used to simulate the compatibility between Mishrif formation water with three various kinds of surface waters: Sea Water (SW), Euphrates River Water (ERW), and the Main Outfall Drain Water (MODW), and predict the amount of possible scaling results from the mixing of different ratios under reservoir conditions. The chemical compositions of the Mishrif waters are classified as Brine water due to the high value of $\mathrm{Ca}^{2+}$ and $\mathrm{Na}^{2+}$ concentration. The waters from the sea, Main Drain Outfall, and the Euphrates River are classified as slightly Brackish waters. All the studied water samples were classified as sodium chloride type $(\mathrm{NaCl})$ due to the increase of evaporation processes, aside from agricultural and domestic activities. The hydrogeochemical facies of the present water samples are fall in $\mathrm{NaCl}$, except in the Mishrif formation water, which is located between $\mathrm{NaCl}$ and $\mathrm{MixCaMgCl}$. Scaling prediction models of mixing show that calcium carbonate $\left(\mathrm{CaCO}_{3}\right)$ and Barite $\left(\mathrm{BaSO}_{4}\right)$ is expected to cause serious problems in the Mishrif reservoir when all types of waters mix in different ratios in the absence of scale inhibitors, whereas the model results revealed no problems in Celestite, Aragonite, and Strontianite scales due to their minor precipitation behavior through mixing. Gypsum, Sederite, and Anhydrite tend to dissolve when mixing all types of surface waters in different ratios because of a low saturation index. The simulation results show that the best ratios to mix sea water is 90-10\% formation water, all ratios to mix Main Drain Outfall water, and 70-30 and 90-10\% when mixing Euphrates River water with Mishrif formation water. Chemical inhibitions treatment preferred to be implemented to reduce the carbonate scales during/after water flooding.
\end{abstract}

Keywords Waterflooding $\cdot$ Scaling $\cdot$ Basra oilfield $\cdot$ Mishrif formation $\cdot$ Saturation ration, Iraq

\section{Introduction}

Water flooding is one of the choice methods used to enhance and increase oil production from the oil/gas reservoirs to support reservoir pressure (Jreou 2012), and/or to push oil towards the producer well. However, a new method for waterflood injection is being established. Injection water with significantly lower salinity or presence of ions than sea water or surface water has been shown to have beneficial

Hussein B. Ghalib

hbggeo@hotmail.com

1 Geology Department, Basrah University, Basrah, Iraq effects on oil recovery (Morrow and Buckley 2011). The problem associated with dissolved undesirable minerals and gas in the water injection that affected this method (Erany 2016).

The mineralogy problem is usually caused by chemical reactions of the water injection with the sensitive clay, which swells or becomes dislodged and blocks the reservoir pores. Water quality can be affected by several types of contaminants, including suspended solids, scale, bacteria, corrosion products, and marine organisms. Chemical and biological analyses can provide a useful indicator of future incompatibility, corrosion, and bacterial problems (Mitchell and Bowyer 1982). 
Precipitation of mineral scales causes many problems in oil and gas production operations, such as formation damage, production losses, increased workload for producers and injectors, poor injection water quality, and equipment failure due to under-deposit corrosion. Geochemical reactions between fluids and carbonate rocks can cause significant scaling in and around injection and production wells, leading to high operating costs. The most common mineral scales are sulfate- and carbonate-based minerals. However, scale problems are not limited to these minerals, and there have been recent reports of unusual scale types, such as zinc and lead sulfides (Collins and Jordan 2003).

The aims of this project were to simulate the compatibility between Mishrif formation water with three various kinds of surface waters: Sea water (SW), Euphrates River (ERW), and the Main Outfall Drain water (MODW), and to predict the amount of possible scaling results from the mixing of different rations by using a hydrogeochemical PHEEQC $\mathrm{Vr}$ 3, 2015 computer software program to calculate mineral saturation indices. This calculation is based upon the Pitzer theory of electrolytes, which is generally believed to be the best approach to calculate the effect of high temperature, pressure, and total dissolved solids (TDS) in the composition of activity coefficients using Pitzer equations (Pitzer 1991).

Although the South Oil Company in Basrah province may become accustomed to the use of Qarmat Ali water for injections, it is also hoped that the company can use the Main Outfall Drain water. Sea water is commonly used as a source of injecting water, especially in offshore field areas, as in the Basrah oil fields. However, injecting natural sea water is recognized to have no significant effects on the oil field recovery. The high content of hardness ions, such as $\mathrm{SO}_{4}{ }^{2-}$ and $\mathrm{CO}_{3}{ }^{2-}$, are believed to induce more scale depositions when in contact with formation water. Costly treatments and environmental issues are a constraint when applying conventional water injections.

Starting in 1975, the Mishrif reservoir in the West Qurna Oilfield started to produce without any energy supply, and most producers ceased to produce because of low reservoir pressure. Therefore, a water injection pilot was conducted starting in 2010, and the expanded water injection began in 2013. After 2 years of water injections, several producers are back to production, and the production rate of several wells is increasing significantly. However, a number of problems have arisen, the most significant of which being scaling issues. Geochemical reactions between fluids and carbonate rocks can cause significant scaling in and around injection and production wells, leading to high operating costs (Atiaa and Handhel 2009).

In order to manage this problem, this study highlights the hydrogeochemistry of the oilfield water and the expected damage as a result of sea water, Euphrates River water, and Main Outfall Drain water as injections to the Mishrif reservoir by using a hydrogeochemical PHREEQC Vr 3, 2015 computer software program to calculate mineral saturation indices. This calculation is based upon the Pitzer theory of electrolytes, which is generally believed to be the best approach to calculate the effect of high temperature, pressure, and TDS on the composition of activity coefficients using Pitzer equations (Pitzer 1991).

\section{Mechanisms of scaling and types}

The main sources of oil field scales result from the mixing of incompatible waters, as precipitation minerals could be found as an outcome of this process (Merdhah and Yassin 2008). A typical example of incompatible waters is sea water with a high concentration of $\mathrm{SO}_{4}{ }^{2-}$ and low concentrations of $\mathrm{Ca}^{2+}, \mathrm{Ba}^{2+} / \mathrm{Sr}^{2+}$, and formation waters with very low concentrations of $\mathrm{SO}_{4}{ }^{2-}$, but high concentrations of $\mathrm{Ca}^{2+}$, $\mathrm{Ba}^{2+}$ and $\mathrm{Sr}^{2+}$. The mixing of these waters, therefore, causes precipitation of $\mathrm{CaSO}_{4}, \mathrm{BaSO}_{4}$, and/or $\mathrm{SrSO}_{4}$ (Paulo et al. 2001).

There are many types of scale-like sulfates, such as calcium sulfate (anhydrites, gypsum), barium sulfate (barite), strontium sulfate (celestite) and calcium carbonate (calcite, dolomite). Iron oxides, iron sulfides, and iron carbonates are the less common scales Table 1 (Moghadasi et al. 2003). Calcium carbonate is the predominant scale deposition from natural waters, especially in cooling and heating systems (El-Said et al. 2009). Carbonate scales can impair production by blocking tubing and flow lines, fouling equipment, and concealing corrosion (Zhang et al. 2001). The variety of ions that exist in the formation and injection waters, such as $\mathrm{Mg}^{2+}, \mathrm{Ba}^{2+}, \mathrm{Sr}^{2+}, \mathrm{Mn}^{2+}$ and $\mathrm{SO}_{4}{ }^{2-}$, can affect $\mathrm{CaCO}_{3}$ growth rate (Akin and Lagerwerff 1965).

\section{Factors affected the scaling precipitation}

The total dissolved solids and $\mathrm{pH}$ affect the permeability of the main reservoir. Clay minerals (like kaolinite and Montmorellonite) are considered as the main reasons behind the damage of oil formations. They can affect negatively formation characteristics through their dispersion and swelling due to the changes of chemical characteristics of the contact water (Scheuerman and Bergersen 1989). Clay mineral types will vary in their influence on the permeability of the formation depending on the basic silica structure, which varies from mineral to another (Al-Mallah 2014).

Increasing the temperature may increase or decrease the solubility of minerals, depending on the nature of the system. For example, if the dissolution process is exothermic, then the solubility decreases with increased temperature; if endothermic, then the solubility increases with temperature. The factors that affect scale precipitation, deposition, and 
Table 1 Most common oilfield scales (Moghadasi et al. 2003)

\begin{tabular}{|c|c|c|}
\hline Scale name & Chemical formula & Primary variables \\
\hline Calcium carbonate & $\mathrm{CaCO}_{3}$ & $\begin{array}{l}\text { Partial pressure of } \mathrm{CO}_{2} \text {, temperature, total } \\
\text { dissolved salts, } \mathrm{pH}\end{array}$ \\
\hline \multicolumn{3}{|l|}{ Calcium sulfates } \\
\hline Gypsum & $\mathrm{CaSO}_{4} \cdot 2 \mathrm{H}_{2} \mathrm{O}$ & Temperature \\
\hline Anhydrite & $\mathrm{CaSO}_{4}$ & Pressure \\
\hline Hemihydrate & $\mathrm{CaSO}_{4} \cdot \mathrm{H}_{2} \mathrm{O}$ & Total dissolved salts \\
\hline Barium sulfate & $\mathrm{BaSO}_{4}$ & Temperature, pressure \\
\hline Strontium sulfate & $\mathrm{SrSO}_{4}$ & Temperature, pressure, total dissolved salts \\
\hline \multicolumn{3}{|l|}{ Iron compounds } \\
\hline Ferrous carbonate & $\mathrm{FeCO}_{3}$ & Corrosion \\
\hline Ferrous sulfide & $\mathrm{FeS}$ & Dissolved gases \\
\hline Ferrous hydroxide & $\mathrm{Fe}(\mathrm{OH})_{2}$ & $\mathrm{pH}$ \\
\hline Ferrous hydroxide & $\mathrm{Fe}(\mathrm{OH})_{3}$ & \\
\hline
\end{tabular}

crystal growth are super saturation, temperature, pressure, ionic strength, evaporation, contact time, and $\mathrm{pH}$ (Burchette 1993).

\section{Geological and stratigraphic setting}

The Mishrif formation is considered as one of the main productive reservoirs in southern Iraq that comprises an important place into the stratigraphic column of the middle Cretaceous period. It reflects the continuous deposition on a shallow carbonate platform developed during the Upper Cenomanian to Early Turonian period (Al-Mohammad 2012). Petrographic study and microfacies analyses revealed five main sub-environments: shallow restricted, shallow open marine, shoal, Rudist biostrom, and deep marine environments. Following a geologic log interpretation and microfacies analysis, the Mishrif formation was subdivided into five reservoir units (mA, mB1-1, mB1-2, mB2-1, and $\mathrm{mB} 2-2)$. These reservoir units are characterized by high total porosity [18]. Figure 1 shows the stratigraphic column of the South Iraq, Basrah region, with key source rocks, seals, and structural events (Al-Khafaji et al. 2017).

\section{Methodology}

The chemical composition of Mishrif formation water were taken from an internal report of the South Oil company (South Oil Company (SOC) 2012), aside from the surface water (sea water and Euphrates River water), and average physicochemical composition of five Main Drain Outfall stations (Table 2; Fig. 2) (Al-Mallah 2014). This was executed in order to evaluate the simulation compatibility between above surface waters with Mishrif formation water, and to predict the scaling precipitation, in addition to evaluating the mineral saturation indices, resulting from the mixing of different ratios of injection waters and formation water under reservoir conditions.

A hydrogeochemical PHEEQC Vr 3, 2015 computer software program (South Oil Company (SOC) 2012), which was written in the $\mathrm{C}$ programming language, was used to calculate the mineral saturation indices using Pitzer equations for the calculation of the activity coefficients in highly saline waters (Pitzer 1991). Mathematically, it can be calculated through the following equation:

Saturation indices $(\mathrm{SI})=\frac{I A P}{K s p}$

where product, $\mathrm{K}_{\mathrm{sp}}$ is the equilibrium constant called solubility product, and IAP is the ion activity product. For example, in the case of gypsum dissolution, it would be

$\mathrm{IAP}=\left[\mathrm{Ca}^{2+}\right]\left[\mathrm{SO}_{4}{ }^{2-}\right]$

where brackets denote activities.

Water is considered as an equilibrium with respect to a given mineral; when IAP $=\mathrm{Ksp}$, the saturation index value is 0 . Water is supersaturated and the mineral should precipitate when the saturation index is greater than 0 . If the saturation index value less than 0 , the water is undersaturated and the mineral should dissolve (of course, if the mineral is present in a solid phase in contact with the water) (South Oil Company (SOC) 2012).

\section{Chemical composition of formation water, and present surface waters}

The chemical composition of the Mishrif Formation water and all the present studied waters are shown in Table 2. All the present studied water samples are characterized by weak alkaline types. According to (Parkhurst and Appelo 


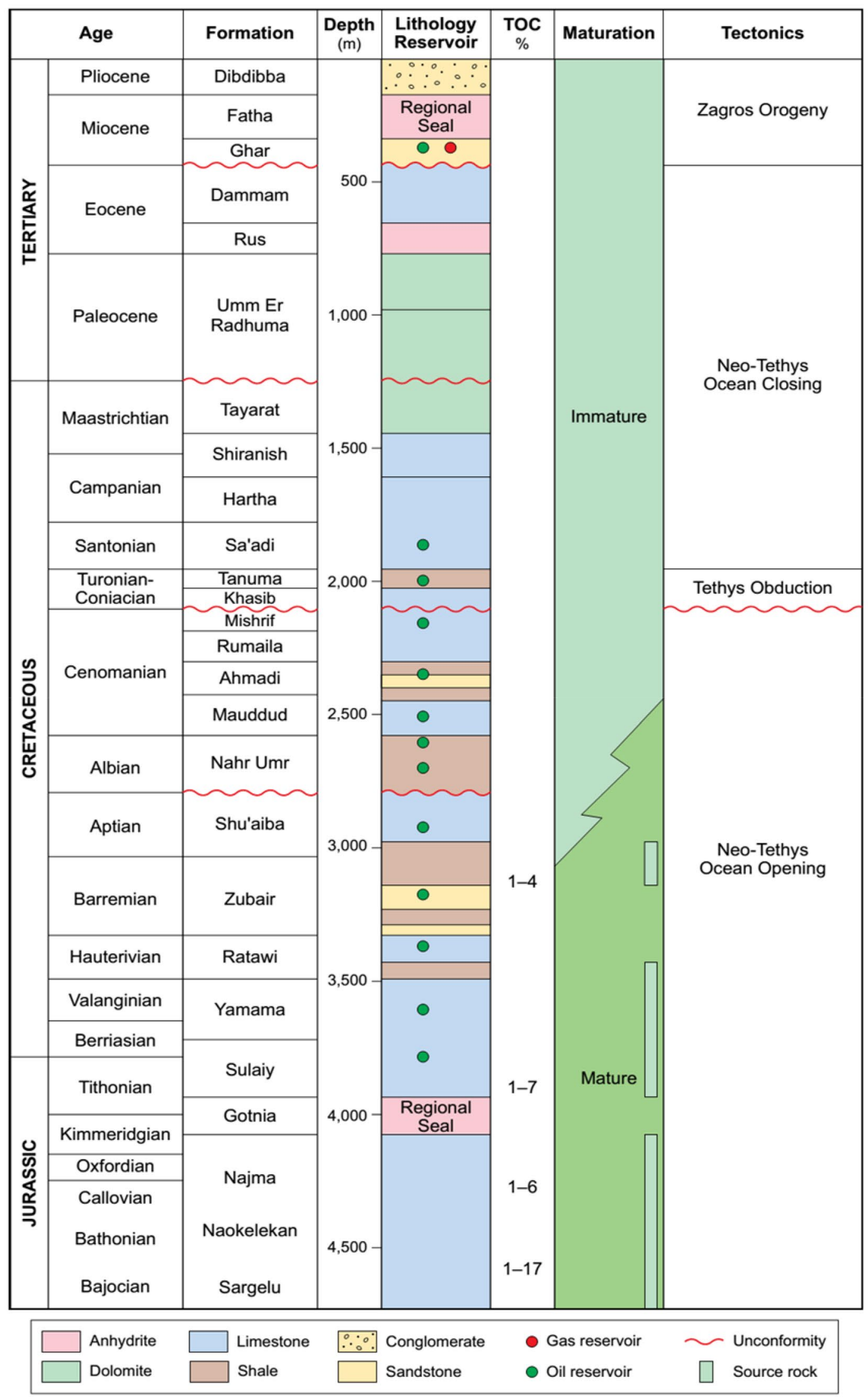

Fig. 1 Stratigraphic column of South Iraq, Basrah region showing key source rocks, seals, and structural events (Al-Ameri et al. 2011) 
Table 2 Basic characteristics of Mishrif formation water and present surface waters

\begin{tabular}{|c|c|c|c|c|}
\hline Sample identification & $\begin{array}{l}\text { Mishrif formation } \\
\text { water }\end{array}$ & $\begin{array}{l}\text { Arab Gulf Sea } \\
\text { water }\end{array}$ & Euphrates water & $\begin{array}{l}\text { Main } \\
\text { Outfal } \\
\text { Drain }\end{array}$ \\
\hline Sampling date & $16 / 07 / 2012$ & 2013 & 2010 & 2012 \\
\hline \multicolumn{5}{|l|}{ Cations(mg/L) } \\
\hline $\mathrm{Na}^{+}$ & 62,093 & 13,358 & 166.4 & 2480 \\
\hline $\mathrm{Ca}^{2+}$ & 2905 & 357 & 89.18 & 284 \\
\hline $\mathrm{Mg}^{2+}$ & 422 & 1230 & 36.21 & 382 \\
\hline $\mathrm{Fe}^{-}$ & 2 & $<0.1$ & $<0.2$ & 0.4 \\
\hline $\mathrm{Ba}^{2+}$ & 4 & $<0.1$ & 0.2 & 0.1 \\
\hline $\mathrm{K}^{+}$ & 22,682 & 354 & & 20 \\
\hline $\mathrm{Sr}$ & 137 & 8 & 6 & 7 \\
\hline \multicolumn{5}{|l|}{ Anions (mg/L) } \\
\hline $\mathrm{Cl}^{-}$ & 119,565 & 22,583 & 219.9 & 2660 \\
\hline $\mathrm{SO}_{4}^{2-}$ & 4075 & 3359 & 288.2 & 1440 \\
\hline $\mathrm{HCO}_{3}^{-}$ & 415 & 130 & 162.3 & 210 \\
\hline $\mathrm{CO}_{3}^{-}$ & 0 & 0 & 0 & 0 \\
\hline $\mathrm{Br}^{-}$ & 849.8 & 0 & 0.53 & 89.38 \\
\hline \multicolumn{5}{|l|}{ Resistivity (ohm-meters) } \\
\hline$@ 75^{\circ} \mathrm{F}$ & 0.0467 & 0.166 & & 1.05 \\
\hline TDS (mg/L) & 212,296 & 41,379 & 7430 & 8104 \\
\hline $\mathrm{T}\left(\mathrm{C}^{\circ}\right)$ & 87.7 & 25 & 25 & 26 \\
\hline PH & 7.27 & 7.88 & 8.23 & 8.15 \\
\hline
\end{tabular}

2013) Table 3, pH is considered as an important parameter to control the solubility of many salts in a system (Komatina 2004). Therefore, the results may have negative effects on the reservoir due to the deposition of carbonate components, which reduces the permeability.

The total dissolved solids of Mishrif formation water is classified as Brine water (high saline water) due to the high value of $\mathrm{Ca}^{2+}$ and $\mathrm{Na}^{2+}$ concentration, which increases the salinity. Sea water, Euphrates River water, and Main Drain Outfall water are shown to be slightly Brakish waters according to (Hem 2005), whereas it classified as Brakish water according to (Todd 2009), (Table 4).

Cation concentrations results Table 2 , show that Sodium $\mathrm{Na}^{+}$is predominant in Mishrif formation water because of the dissolution of halite and evaporate rocks under the reservoir conditions. In addition, all the oil fields contain more sodium than any other cations due to their marine origin (Collins 1975). Sodium concentration also is the main cation in all the present water samples, which reflects different anthropogenic sources, including industrial, domestic, and animal wastes (Freeze and Cherry 1982).

The anion concentration results reflect that $\mathrm{Cl}^{-}$is the most common anion in Mishrif formation water, which reflects the presence of gypsum-bearing sulfate sedimentary rocks (Janardhana Raju et al. 2011). Main Drain Outfall water shows the same results as the Mishrif formation water, due to the percolation from the sewage and the results of irrigation activities (Bhatia 2003). Sulfate $\mathrm{SO}_{4}{ }^{2-}$ was the main anion in sea water and Euphrates River water because of the high salinity and leaching of industrial and domestic sewage, which led to an increase in its concentration (Ramkumar et al. 2010).

Stiff pattern diagram is one of the hydrogeochemical graphical analysis methods used to represent chemical analyses by four parallel axes; concentrations of cations are plotted to the left of the vertical zero axis, and anions are plotted to the right (Todd 2009). The studied water samples are illustrated in Fig. 3, in which all the patterns show that all studied water samples under $\mathrm{NaCl}$ emphasized increasing the evaporation processes and sewage of agricultural and domestic activities that resulted towards the water systems, in addition to increasing the weathering of magnesium and sodium sulfate minerals (Esmaeili and Moore 2012). Dissolution of evaporates and carbonate rocks under the reservoir condition will increase ion solubility in water formation, in addition to the presence of gypsum-bearing sulphate sedimentary rocks (Janardhana Raju et al. 2011).

\section{Hydrochemical facies}

Piper diagrams are a geochemical graphic analysis method used in surface and groundwater studies. They can assist in evaluating the mechanisms of flow and transport in addition to ascertaining paleoenvironmental information 


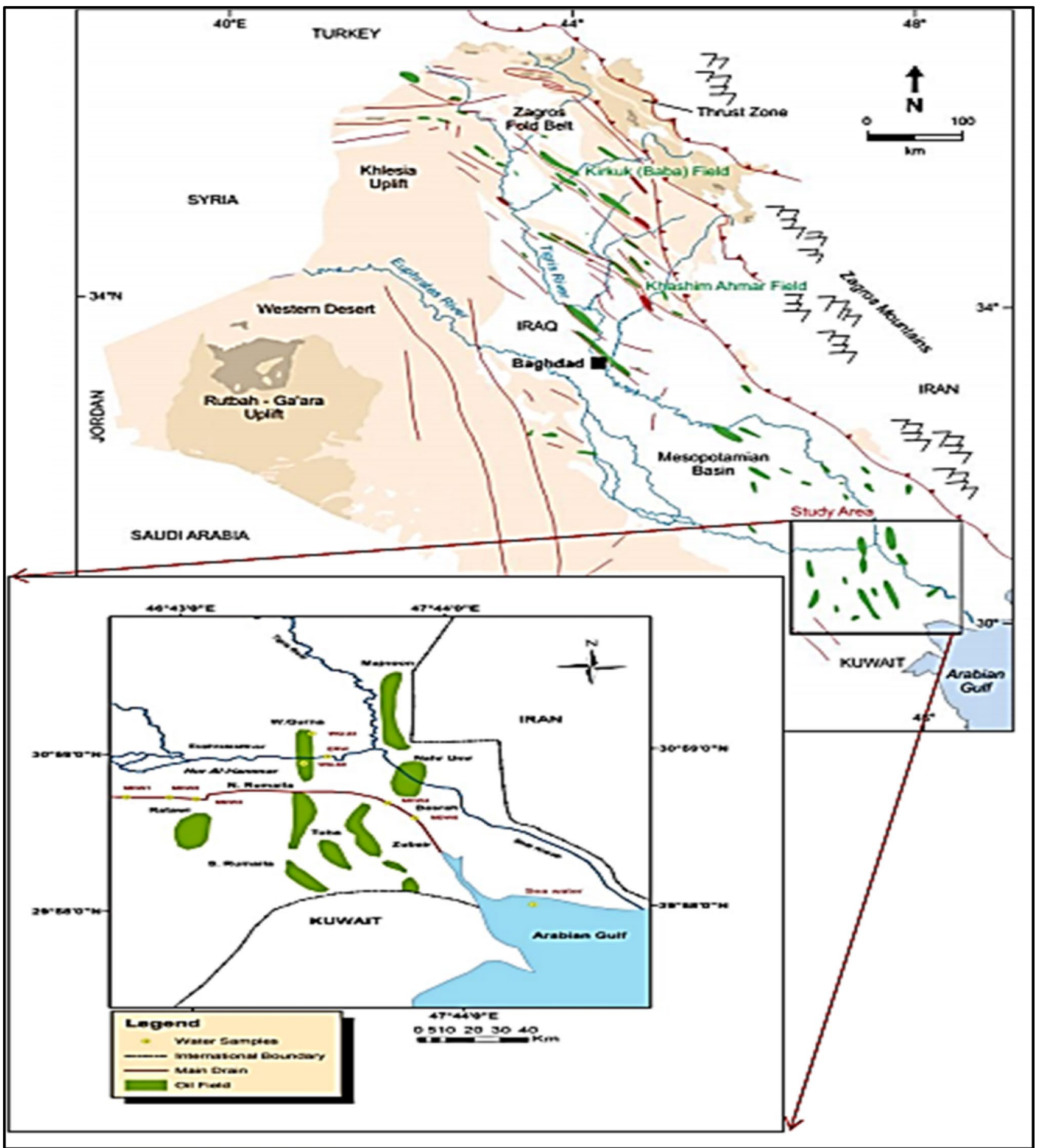

Fig. 2 Study area location map

(Ghalib 2017). A piper diagram of the studied water samples is shown in Fig. 4, in which all present water samples fell under Sodium chloride type $(\mathrm{NaCl})$, except in the Mishrif formation water, which was located between $\mathrm{NaCl}$ and
MixCaMgCl type, which represents $\mathrm{Na}^{+}-\mathrm{K}^{+}-\mathrm{Cl}^{-}-\mathrm{SO}_{4}{ }^{2-}$. From the cationic and anionic triangular field of the piper diagram, Mishrif is observed to be located in the zone of sodium type with no dominate anion type. 
Table 3 Classification of water quality depending on the value of the pH (Komatina 2004)

\begin{tabular}{ll}
\hline Value of pH & Water quality \\
\hline$>3.5$ & Strongly acid \\
$3.5-<5.5$ & Moderate acidic \\
$5.5-<6.8$ & Weakly acidic \\
$6.8-<7.2$ & Neutral \\
$7.2-<8.5$ & Weakly alkaline \\
8.5 and more & Alkaline \\
\hline
\end{tabular}

Table 4 Classification of groundwater according to the TDS (mg/L)

\begin{tabular}{ll}
\hline According to Freeze and Cherry (1979) & \\
TDS & Water class \\
$<1000$ & Fresh water type \\
$1,000-10,000$ & Brackish water type \\
$10,000-100,000$ & Saline water type \\
$>100,000$ & Brine water type \\
According to Todd (2007) & \\
TDS & Water class \\
$10-1000$ & Fresh water \\
$1000-10,000$ & Slightly-Brackish water \\
$10,000-100,000$ & Brackish water \\
$>100,000$ & Brine water \\
\hline
\end{tabular}

The hydrogeochemical facies that could be recognized from Fig. 7 show that Mishrif formation water falls under the mixed $\mathrm{CaMgCl}$ type, which suggests the dissolution of carbonate and evaporate minerals. In general, alkalis $(\mathrm{Na}+\mathrm{K})$ significantly dominate more than the alkali earth elements $\left(\mathrm{Ca}^{2+}\right.$ and $\left.\mathrm{Mg}^{2+}\right)$, and strong acids $\left(\mathrm{Cl}^{-}\right.$and $\left.\mathrm{SO}_{4}{ }^{2-}\right)$ dominate more than weak acids $\left(\mathrm{CO}_{3}{ }^{-}\right.$and $\left.\mathrm{HCO}_{3}{ }^{-}\right)$.

\section{Results and discussion}

The calculations of mineral saturation indices and the establishment of equilibrium conditions of selected minerals resulting from mixing sea water in Mishrif formation water with different mixing ratios under reservoir conditions are shown in Table 5 (Fig. 5). In general, the results show a supersaturation of Geothite, Dolomite, Calcite, Barite, Strontianite, and Celestite, whereas the predicted results show an undersaturation with Gypsum and Sedirite in any mixing ratios between sea water and Mishrif formation water. Anhydrite saturation indices show a supersaturation of 10 and 30\%, 90 and 70\% of sea water and Mishrif Formation water, respectively. These changes to undersaturation when mixing 50, 70, 90\% of Gulf Sea water, and 50, 30, 10\% of Mishrif Formation water, respectively.
Table 6 shows scale probability depending on saturation ratio (South Oil Company (SOC) 2012). The scale-predicted model for mixing sea water and Mishrif Formation water reveals that only Geothite has a saturation ratio between 4.0 and 10.0, suggesting that scales will possibly precipitate. Dolomite, Barite, Calcite, and Aragonite were predicted to be supersaturated where these waters mixed, and these scales are unlikely or minor to precipitate due to the lower expected saturation ratios, which are between 1.0 and 4.0. Therefore, a periodic inhibition treatment should be carried out through mixing.

The mixing predicted model of the Euphrates River water injection in Mishrif Formation water tends to precipitate Geothite, Dolomite, Calcite, Aragonite, Barite, and Strontianite, with a decrease in their saturation ratio and an increase of the Euphrates River water ratio Table 7 (Fig. 6), in which all these scales are supersaturated under reservoir conditions. Celestite tends to precipitate through mixing $50 \%$ Euphrates River water with 50\% Mishrif Formation water, then tends dissolve in 70 and $90 \%$ of Euphrates River water with 30 and $10 \%$ of Mishrif Formation water. Anhydrite scales results show an undersaturation when the two waters mix, in addition to Gypsum, Halite, and Siderite scales.

According to Table 6, the scale predicted model for mixing Euphrates River water and Mishrif Formation water shows the same results as when injecting sea water, as only Geothite has the possibility to precipitate. Dolomite, Calcite, Aragonite, and Barite were predicted to be supersaturated when these waters mixed, and these scales are unlikely or minor to precipitate. However, there was no problem with Strontionite, Celestite, and Anhydrite, as no inhibition treatment would be needed because no precipitation will be found.

Table 8 shows the results of the simulation mixing ratio results of injecting the Main Drain Outfall water in the Mishrif Formation. The predicted saturation index results from the mixing model show that Geothite, Dolomite, Calcite, Aragonite, Barite, Strontianite, and Celestite scales were supersaturated under all mixing ratios between Main Drain Outfall and Mishrif Formation waters, while a deposition of Gypsum and Siderite scales that could be predicted as an undersaturated condition of these scales was found in various mixing ratios under the reservoir condition (Fig. 7). Therefore, a high saturation ratio of Geothite-predicted scales will be possible, and a permanent inhibition treatment should be implemented. However, there is no need for Strontionite and Celestite scale inhibition treatment, due to their low saturation ratios, whereas Dolomite, Calcite, Aragonite, and Barite should undergo periodic inhibition treatments because their scales have an unlikely or minor occurrence to precipitate. 
Fig. 3 Stiff diagram of present waters
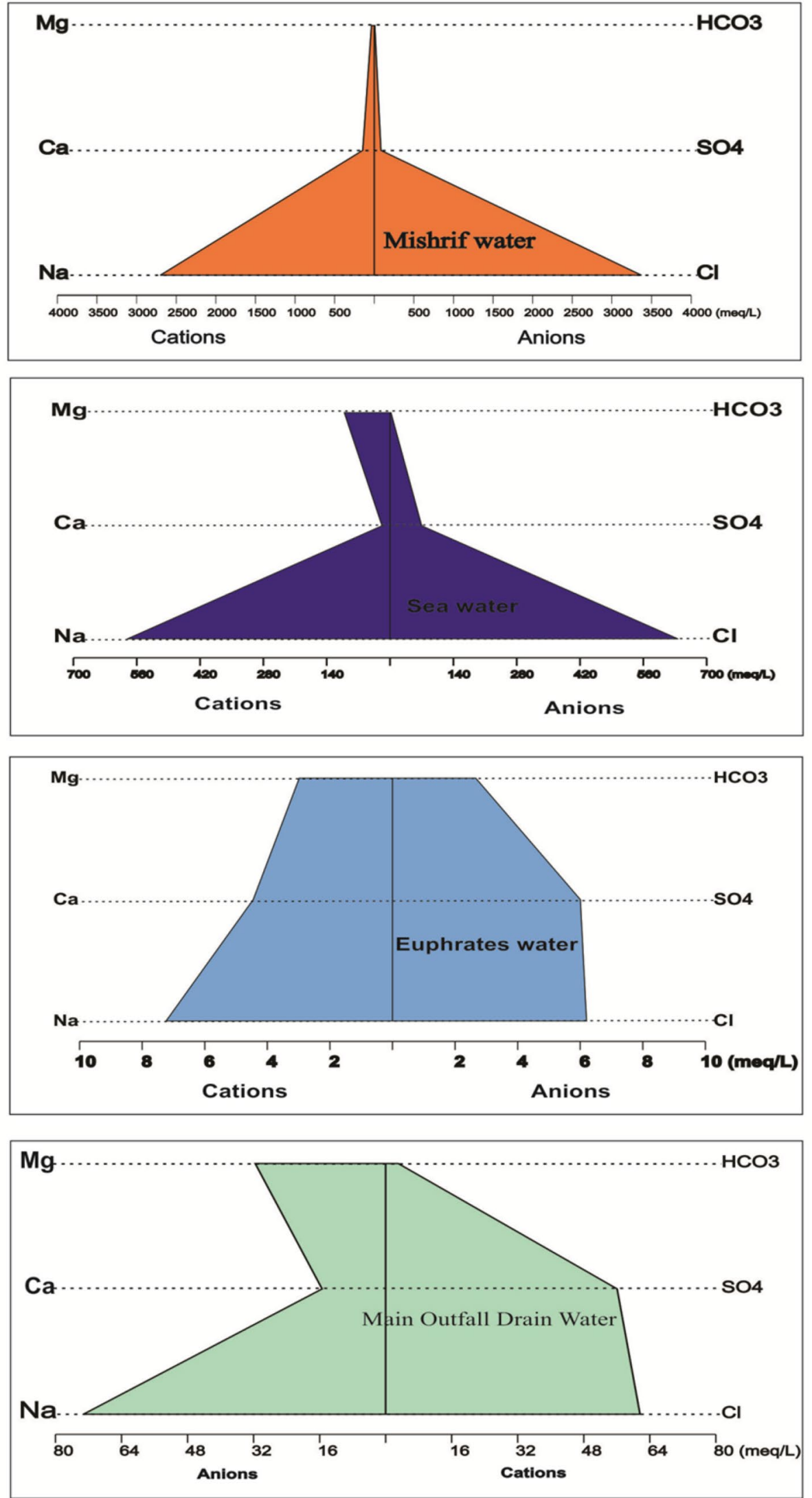


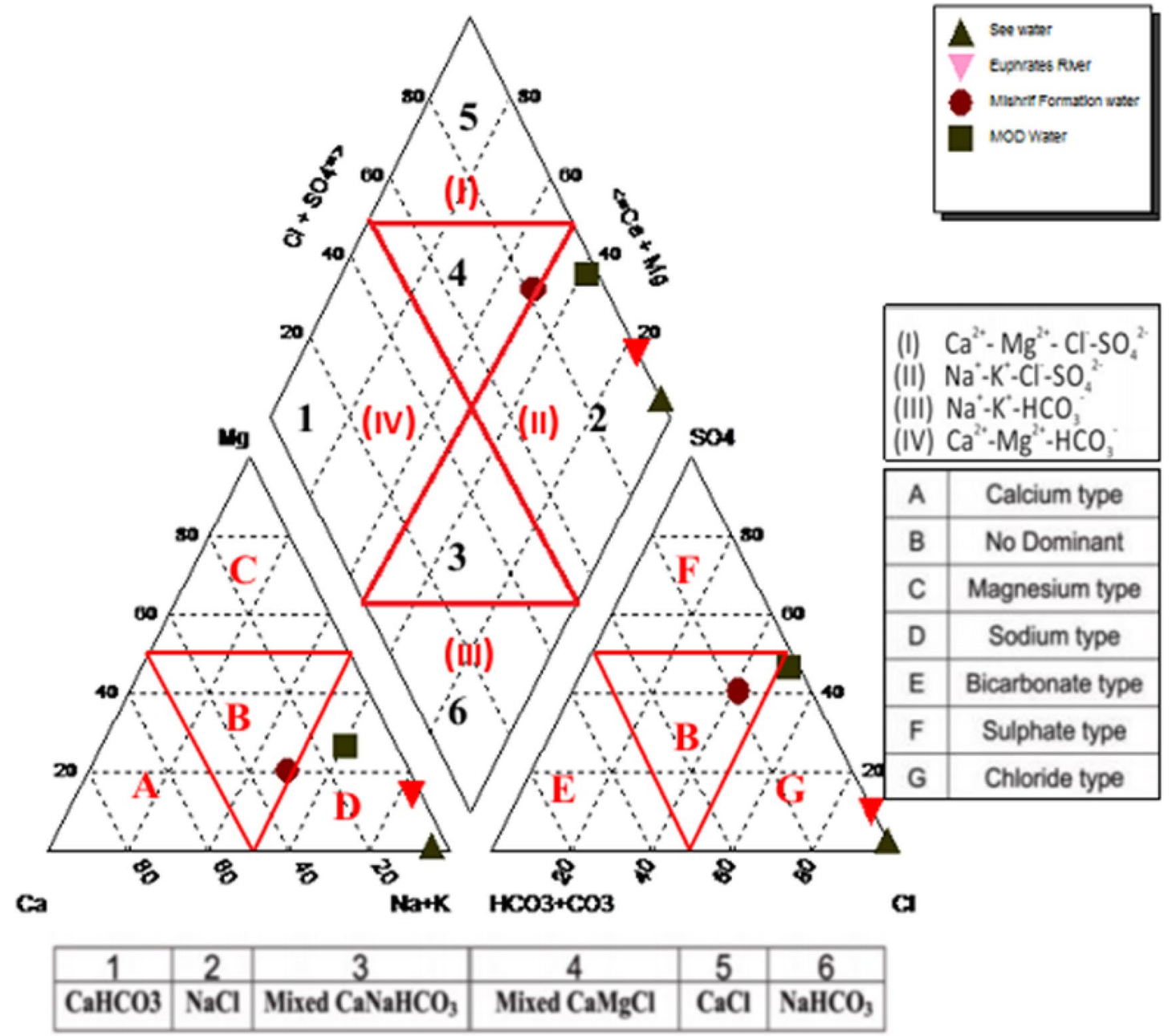

Fig. 4 Piper diagram of water samples of the present study

Table 5 Predicted saturation index for all possible scales resulting from mixing between Mishrif formation water and Gulf sea water under reservoir conditions (software output)

\begin{tabular}{|c|c|c|c|c|c|c|c|c|c|c|}
\hline \multirow[t]{2}{*}{ Mixing ratio } & \multicolumn{10}{|c|}{ Saturation indices of phases } \\
\hline & $\begin{array}{l}\text { Calcite } \\
\left(\mathrm{CaCO}_{3}\right)\end{array}$ & $\begin{array}{l}\text { Aragonite } \\
\left(\mathrm{CaCO}_{3}\right)\end{array}$ & $\begin{array}{l}\text { Dolomite } \\
\left(\mathrm{CaMg}\left(\mathrm{CO}_{3}\right)_{2}\right)\end{array}$ & $\begin{array}{l}\text { Celestite } \\
\left(\mathrm{SrCO}_{3}\right)\end{array}$ & $\begin{array}{l}\text { Gypsum } \\
\left(\mathrm{CaSO}_{4} \cdot 2 \mathrm{H}_{2} \mathrm{O}\right)\end{array}$ & $\begin{array}{l}\text { Anhydrite } \\
\text { (CaSO4) }\end{array}$ & $\begin{array}{l}\text { Geothite } \\
(\mathrm{FeOOH})\end{array}$ & $\begin{array}{l}\text { Siderite } \\
\left(\mathrm{FeCO}_{3}\right)\end{array}$ & $\begin{array}{l}\text { Strontianite } \\
\left(\mathrm{SrCO}_{3}\right)\end{array}$ & $\begin{array}{l}\text { Barite } \\
\left(\mathrm{BaSO}_{4}\right)\end{array}$ \\
\hline Gulf Sea Water & 0.32 & 0.18 & 1.57 & -0.58 & -0.67 & -0.95 & 7.75 & -2.45 & -0.9 & 0.36 \\
\hline Mishrif Water & 1.83 & 1.72 & 3.4 & 0.53 & -0.02 & 0.34 & 8.23 & -2.7 & 0.67 & 1.23 \\
\hline $\begin{array}{l}10 \% \text { Gulf Sea } \\
\text { Water }\end{array}$ & 1.84 & 1.72 & 3.54 & 0.54 & -0.001 & 0.31 & 8.33 & -2.58 & 0.68 & 1.29 \\
\hline $\begin{array}{l}30 \% \text { Gulf Sea } \\
\text { Water }\end{array}$ & 1.65 & 1.53 & 3.38 & 0.43 & -0.1 & 0.09 & 8.39 & -2.49 & 0.53 & 1.27 \\
\hline $\begin{array}{l}50 \% \text { Gulf Sea } \\
\text { Water }\end{array}$ & 1.44 & 1.32 & 3.16 & 0.29 & -0.2 & -0.14 & 8.41 & -2.42 & 0.37 & 1.25 \\
\hline $\begin{array}{l}70 \% \text { Gulf Sea } \\
\text { Water }\end{array}$ & 1.19 & 1.05 & 2.83 & 0.12 & -0.32 & -0.39 & 8.39 & -2.36 & 0.15 & 1.19 \\
\hline $\begin{array}{l}90 \% \text { Gulf Sea } \\
\text { Water }\end{array}$ & 0.76 & 0.62 & 2.22 & -0.17 & -0.49 & -0.7 & 8.2 & -2.36 & -0.29 & 0.99 \\
\hline
\end{tabular}




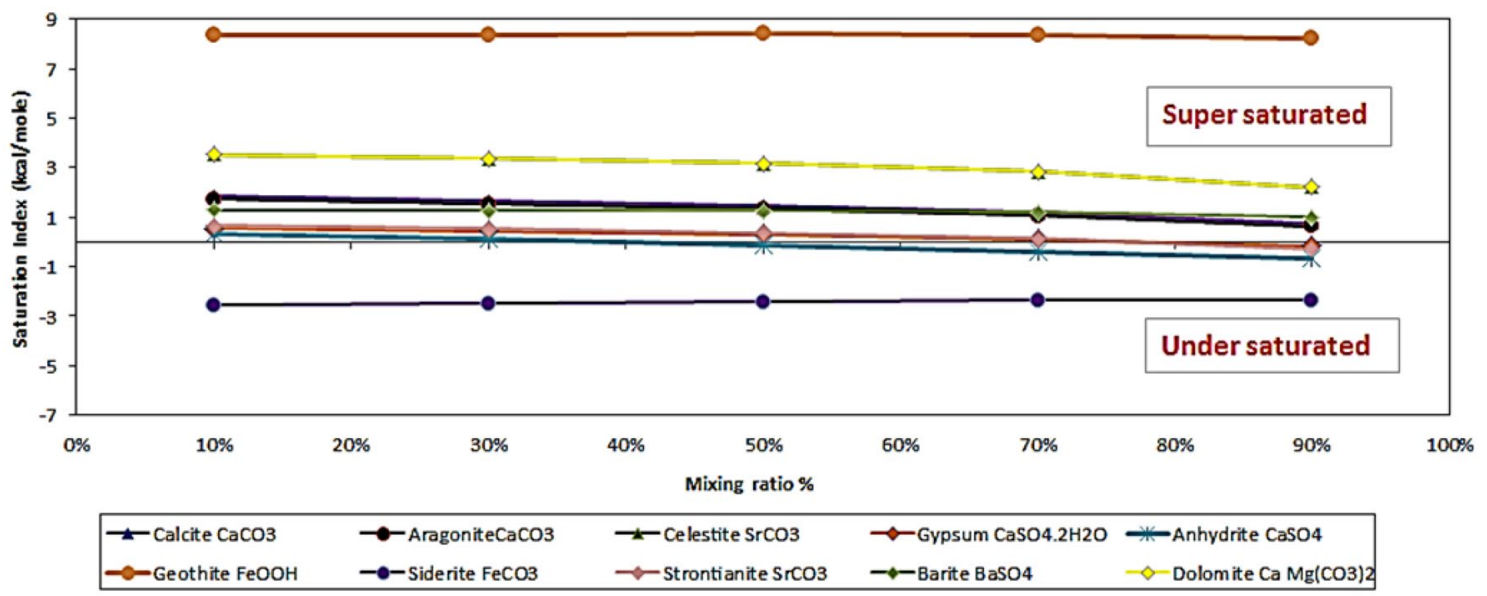

Fig. 5 Saturation indices of the mixture of Mishrif Formation water and Sea water at the reservoir conditions

Table 6 The scale probability according to scale type and ratio (South Oil Company (SOC) 2012)

\begin{tabular}{ll}
\hline Saturation ratio (Vary by scale type) & Risk assessment \\
\hline$<1.0$ no need inhibition treatment & Scale under saturated, no precipitation \\
$1.0-4.0$ periodic inhibition treatment & Scale unlikely or a minor occurrence \\
$4.0-10.0$ periodic / permanent inhibition treatment & Scale possible \\
$>10.0$ permanent inhibition treatment & Scale very likely \\
\hline
\end{tabular}

Table 7 Predicted scale tendency for all possible scales resulting from mixing between Mishrif formation water and Euphrates River water under reservoir conditions (software output)

\begin{tabular}{|c|c|c|c|c|c|c|c|c|c|c|}
\hline \multirow[t]{2}{*}{ Mixing rratio } & \multicolumn{10}{|c|}{ Saturation indices of phases } \\
\hline & $\begin{array}{l}\text { Calcite } \\
\left(\mathrm{CaCO}_{3}\right)\end{array}$ & $\begin{array}{l}\text { Aragonite } \\
\left(\mathrm{CaCO}_{3}\right)\end{array}$ & $\begin{array}{l}\text { Dolomite } \\
\left(\mathrm{CaMg}\left(\mathrm{CO}_{3}\right)_{2}\right)\end{array}$ & $\begin{array}{l}\text { Celestite } \\
\left(\mathrm{SrCO}_{3}\right)\end{array}$ & $\begin{array}{l}\text { Gypsum } \\
\left(\mathrm{CaSO}_{4} \cdot 2 \mathrm{H}_{2} \mathrm{O}\right)\end{array}$ & $\begin{array}{l}\text { Anhydrite } \\
\left(\mathrm{CaSO}_{4}\right)\end{array}$ & $\begin{array}{l}\text { Geothite } \\
(\mathrm{FeOOH})\end{array}$ & $\begin{array}{l}\text { Siderite } \\
\left(\mathrm{FeCO}_{3}\right)\end{array}$ & $\begin{array}{l}\text { Strontianite } \\
\left(\mathrm{SrCO}_{3}\right)\end{array}$ & $\begin{array}{l}\text { Barite } \\
\left(\mathrm{BaSO}_{4}\right)\end{array}$ \\
\hline Euphrates water & 0.67 & 0.52 & 1.28 & -0.65 & -1.22 & -1.52 & 8.03 & -2.62 & -0.06 & 0.77 \\
\hline Mishrif Water & 1.83 & 1.72 & 3.4 & 0.53 & -0.02 & 0.34 & 8.23 & -2.7 & 0.67 & 1.23 \\
\hline $\begin{array}{l}\text { 10\% Euphrates } \\
\text { water }\end{array}$ & 1.84 & 1.72 & 3.45 & 0.52 & -0.03 & 0.28 & 8.33 & -2.6 & 0.68 & 1.27 \\
\hline $\begin{array}{l}\text { 30\% Euphrates } \\
\text { water }\end{array}$ & 1.65 & 1.53 & 3.11 & 0.36 & -0.18 & -0.001 & 8.38 & -2.59 & 0.55 & 1.21 \\
\hline $\begin{array}{l}50 \% \text { Euphrates } \\
\text { water }\end{array}$ & 1.44 & 1.32 & 2.7 & 0.16 & -0.36 & -0.32 & 8.41 & -2.6 & 0.41 & 1.13 \\
\hline $\begin{array}{l}\text { 70\% Euphrates } \\
\text { water }\end{array}$ & 1.22 & 1.08 & 2.21 & -0.1 & -0.6 & -0.69 & 8.39 & -2.64 & 0.26 & 1.01 \\
\hline $\begin{array}{l}\text { 90\% Euphrates } \\
\text { water }\end{array}$ & 0.89 & 0.75 & 1.51 & -0.5 & -0.98 & -1.21 & 8.26 & -2.74 & 0.02 & 0.79 \\
\hline
\end{tabular}

\section{Conclusion}

- For the Mishrif formation using sea water for injection, the results of the scale prediction model show that the most common oilfield scales represented by carbonate and sulfate minerals had a possibility to precipitate. Anhydrite and gypsum is unlikely or a minor occurrence.
- Using Euphrates water in injections were found to generate the same results as the sea water prediction model. The carbonate and sulfate minerals were the main precipitated scales, whereas other predicted scales were not expected to cause major problems as they dissolved under reservoir conditions. 


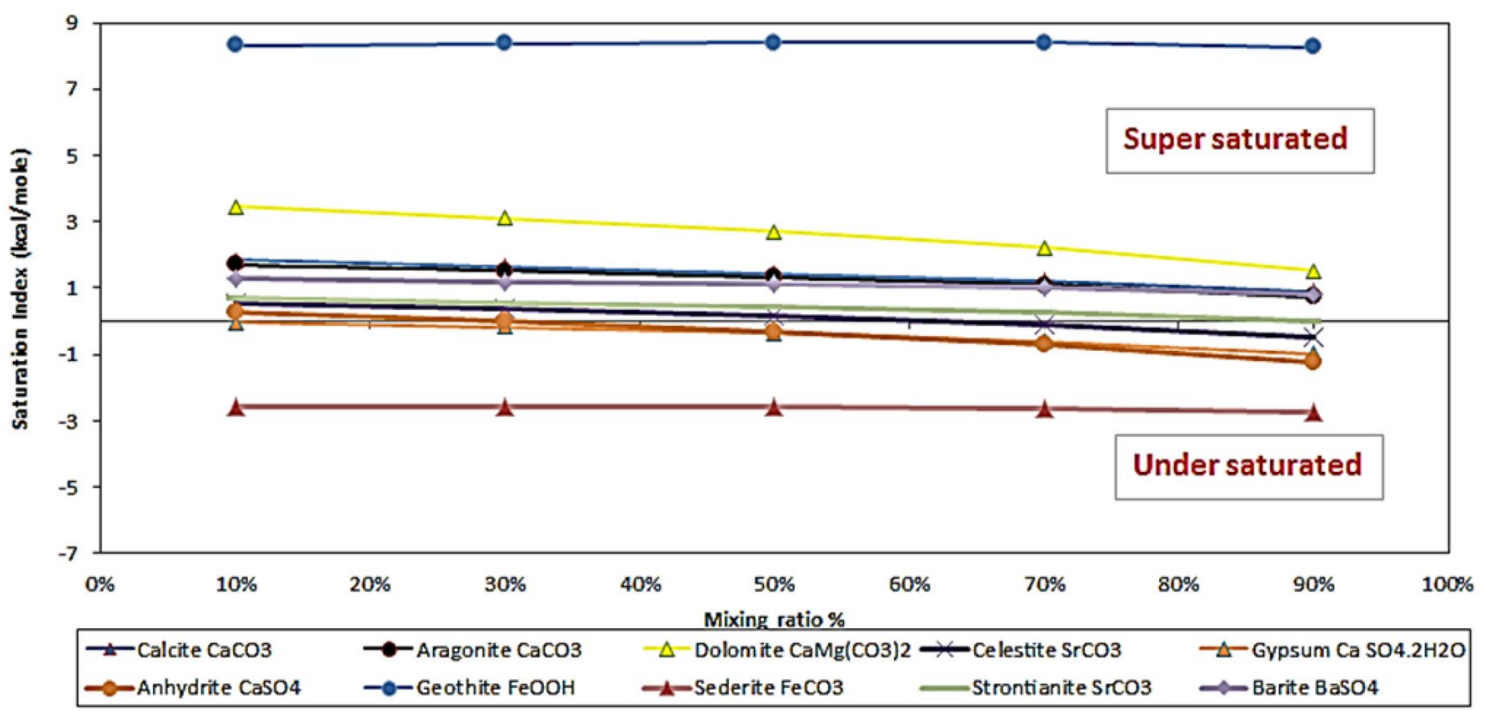

Fig. 6 Saturation indices of the mixture of Mishrif formation water and Euphrates River water at the reservoir conditions

Table 8 Predicted scale tendency for all possible scales resulting from mixing between Mishrif formation water and Main Drain water under reservoir conditions (software output)

\begin{tabular}{|c|c|c|c|c|c|c|c|c|c|c|}
\hline \multirow[t]{2}{*}{ Mixing ratio } & \multicolumn{10}{|c|}{ Saturation indices of phases } \\
\hline & $\begin{array}{l}\text { Calcite } \\
\left(\mathrm{CaCO}_{3}\right)\end{array}$ & $\begin{array}{l}\text { Aragonite } \\
\left(\mathrm{CaCO}_{3}\right)\end{array}$ & $\begin{array}{l}\text { Dolomite } \\
\left(\mathrm{CaMg}\left(\mathrm{CO}_{3}\right)_{2}\right)\end{array}$ & $\begin{array}{l}\text { Celestite } \\
\left(\mathrm{SrCO}_{3}\right)\end{array}$ & $\begin{array}{l}\text { Gypsum } \\
\left(\mathrm{CaSO}_{4} \cdot 2 \mathrm{H}_{2} \mathrm{O}\right)\end{array}$ & $\begin{array}{l}\text { Anhydrite } \\
\left(\mathrm{CaSO}_{4}\right)\end{array}$ & $\begin{array}{l}\text { Geothite } \\
\text { (FeOOH) }\end{array}$ & $\begin{array}{l}\text { Siderite } \\
\left(\mathrm{FeCO}_{3}\right)\end{array}$ & $\begin{array}{l}\text { Strontianite } \\
\left(\mathrm{SrCO}_{3}\right)\end{array}$ & $\begin{array}{l}\text { Barite } \\
\left(\mathrm{BaSO}_{4}\right)\end{array}$ \\
\hline Main Drain water & 1.83 & 1.72 & 3.4 & 0.53 & -0.02 & 0.34 & 8.23 & -2.09 & -0.31 & 0.71 \\
\hline Mishrif Water & 1.75 & 1.64 & 3.3 & 0.48 & -0.07 & 0.23 & 8.27 & -2.7 & 0.67 & 1.23 \\
\hline $\begin{array}{l}10 \% \text { Main Drain } \\
\text { water }\end{array}$ & 1.59 & 1.47 & 3.08 & 0.38 & -0.15 & 0.02 & 8.33 & -2.66 & 0.61 & 1.23 \\
\hline $\begin{array}{l}\text { 30\% Main Drain } \\
\text { water }\end{array}$ & 1.43 & 1.3 & 2.85 & 0.26 & -0.24 & -0.2 & 8.39 & -2.59 & 0.49 & 1.22 \\
\hline $\begin{array}{l}50 \% \text { Main Drain } \\
\text { water }\end{array}$ & 1.26 & 1.12 & 2.6 & 0.13 & -0.32 & -0.41 & 8.42 & -2.51 & 0.38 & 1.21 \\
\hline $\begin{array}{l}\text { 70\% Main Drain } \\
\text { water }\end{array}$ & 1.04 & 0.9 & 2.32 & -0.05 & -0.37 & -0.6 & 8.4 & -2.4 & 0.24 & 1.2 \\
\hline $\begin{array}{l}90 \% \text { Main Drain } \\
\text { water }\end{array}$ & 1.83 & 1.72 & 3.4 & 0.53 & -0.02 & 0.34 & 8.23 & -2.25 & 0.01 & 1.12 \\
\hline
\end{tabular}

- Scaling simulation results of mixing Main Drain Outfall water with different ratios showed supersaturation and a possibility of precipitating calcite and barite minerals. However, the other predicted scales were not expected to cause major problems under reservoir conditions.

- Anhydrite, Gypsum, and Sederite scales in any mixing ratios showed no need for any inhibition treatments because of a low saturation index while tending to be undersaturated.

- All the scale-predicting models of the surface water injection results revealed compatibility with formation water, with the consideration of implementing a chemical inhibition treatment through mixing to avoid or reduce Calcite and Barite scale precipitation. 


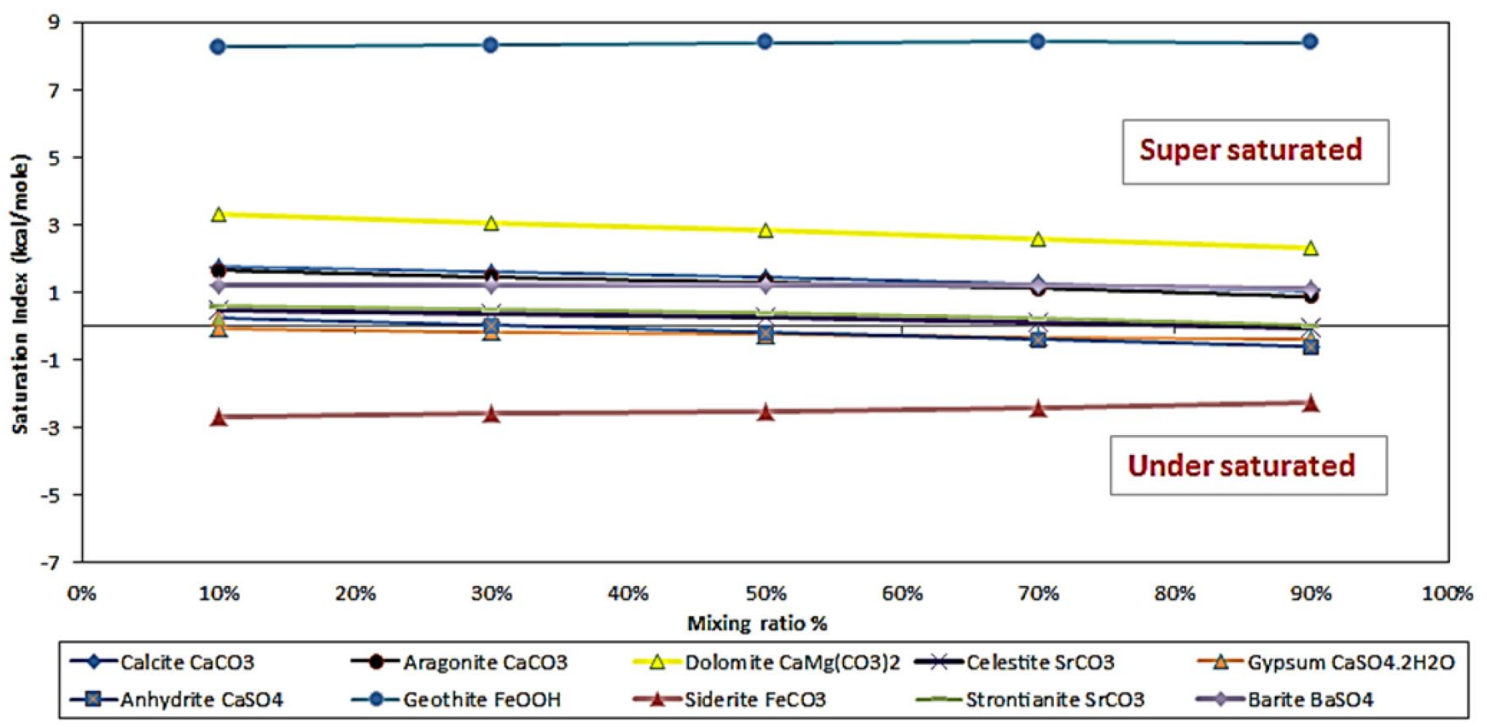

Fig. 7 Saturation indices of the mixture of Mishrif formation water and Main Drain water the reservoir conditions

Acknowledgements The authors are grateful to all anonymous reviewers and also thankful to Mr Hussein Saeed Almalki in Basrah Oil company and University of Basrah for providing necessary facilities.

Open Access This article is distributed under the terms of the Creative Commons Attribution 4.0 International License (http://creativeco mmons.org/licenses/by/4.0/), which permits unrestricted use, distribution, and reproduction in any medium, provided you give appropriate credit to the original author(s) and the source, provide a link to the Creative Commons license, and indicate if changes were made.

\section{References}

Akin G, Lagerwerff J (1965) Calcium carbonate equilibria in solutions open to the air. II. Enhanced solubility of $\mathrm{CaCO}_{3}$ in the presence of $\mathrm{Mg}^{2+}$ and $\mathrm{SO}_{4}{ }^{2-}$ Geochimica. et Cosmochim Acta 29:353-360

Al-Ameri TK, Jafar MS, Pitman J (2011) Hydrocarbon generation modeling of the Basrah oil fields, Southern Iraq. University of Baghdad, Jadiriyah

Al-Khafaji AJ, Hakimi MH, Najaf AA (2017) Organic geochemistry characterisation of crude oils from Mishrif reservoir rocks in the southern Mesopotamian Basin. Implication for source input and paleoenvironmental conditions. Egypt J Pet, South Iraq

Al-Mallah IA (2014) Assessment of the environmental, hydrological and hydrogeological changes of the Main Drain, Iraq. Higher Dectoral thesis. Univ of Basrah, Iraq

Al-Mohammad R (2012) Depositional environment and petrophysical properties Study of Mishrif Formation in Tuba Oilfield, Southern Iraq. J Basrah Res Sci 38:25-50

Atiaa AM, Handhel AM (2009) Fuzzy logic approach to infer reservoir permeability from depth and porosity measurements for Mishrif Limestone formation at Nasyria oil field, south of Iraq. J Al-Anbar Univ Pure Sci 3(1):1-9

Bhatia H (2003) A textbook on environmental pollution and control. Galgotia Publications Private Limited, Delhi

Burchette TP (1993) Mishrif formation (Cenomanian-Turonian), southern Arabian Gulf: carbonate platform growth along a cratonic basin margin. In: Simo JA, Scott RW, Masse J-P (eds) Cretaceous carbonate platforms. AAPG Memoir vol 56, pp 185-199

Collins A (1975) Geochemistry of oilfield waters, vol 1. Elsevier, Amsterdam

Collins I, Jordan M (2003) Occurrence, prediction, and prevention of zinc sulfide scale within Gulf Coast and North Sea hightemperature and high-salinity fields. SPE Prod Facil 18:200-209

El-Said M, Ramzi M, Abdel-Moghny T (2009) Analysis of oilfield waters by ion chromatography to determine the composition of. Scale Depos Desalination 249:748-756

Erany R (2016) A study of scale and scaling potential during high salinity and low salinity waterflooding. University of Stavanger, Norway

Esmaeili A, Moore F (2012) Hydrogeochemical assessment of groundwater in Isfahan province. Iran Environ Earth Sci 67:107-120

Freeze RA, Cherry JA (1982) Groundwater. Prentice-Hall, Englewood Cliffs

Ghalib HB (2017) Groundwater chemistry evaluation for drinking and irrigation utilities in East Wassit province. Central Iraq Appl Water Sci

Hem JD (2005) Study and interpretation of the chemical characteristics of natural water. University Press of the Pacific, Honolulu

Janardhana Raju N, Shukla U, Ram P (2011) Hydrogeochemistry for the assessment of groundwater quality in Varanasi: a fasturbanizing center in Uttar Pradesh. India Environ Monit Asses 173:279-300

Jreou GN (2012) Increasing of oil field productivity by implementation of re-entry horizontal injection well, case study. Int J Eng Technol IJET-IJENS Kufa University-Engineering College, Iraq

Komatina M (2004) Medical geology: effects of geological environments on human health, vol 2. Elsevier, Amsterdam

Merdhah AB, Yassin A (2008) Formation damage due to scale formation in porous media resulting water injection system. Emir J Eng Res 13(3):69-79

Mitchell RW, Bowyer PM (1982) Water injection methods. International Petroleum Exhibition and Technical Symposium. Society of Petroleum Engineers 
Moghadasi J, Jamialahmadi M, Müller-Steinhagen H, Sharif A, Ghalambor A, Izadpanah M, Motaie E (2003) Scale formation in Iranian oil reservoir and production equipment during water injection. In: International Symposium on Oilfield Scale. Society of Petroleum Engineers

Morrow N, Buckley J (2011) Improved oil recovery by low-salinity waterflooding. J Petrol Technol 63:106-112

Parkhurst DL, Appelo CAJ (2013) Description of input and examples for PHREEQC version 3-a computer program for speciation, batch-reaction, one-dimensional transport, and inverse geochemical calculations. U.S. geological survey techniques and methods, book 6, chap A43, p 497. https://pubs.usgs.gov/tm/06/a43/

Paulo J, Mackay E, Menzies N, Poynton N Implications of brine mixing in the reservoir for scale management in the alba field. In: International Symposium on Oilfield Scale, 2001. Society of Petroleum Engineers
Pitzer KS (1991) Activity coefficients in electrolyte solutions. CRC press, Boca Raton

Ramkumar T, Venkatramanan S, Anitha Mary I, Tamilselvi M, Ramesh G (2010) hydrogeochemical quality of groundwater in Vedaraniyam town, Tamilnadu, India Research. J Environ Earth Sci 2:44-48

Scheuerman RF, Bergersen BM (1989) Supplement to SPE18461, guidelines for selecting pretreatment and well-operations fluids. SPE-21298-MS

South Oil Company (SOC) (2012) An updated study of reservoir water analyses. Internal report. Baghdad. Iraq (Unpublished)

Todd DK (2009) Groundwater hydrology. John Wiley, New delhi

Zhang Y, Shaw H, Farquhar R, Dawe R (2001) The kinetics of carbonate scaling - application for the prediction of downhole carbonate scaling. J Petrol Sci Eng 29:85-95 